\title{
Small claim, simple recovery? The European small claims procedure and its implementation in the member states
}

\author{
Xandra E. Kramer
}

Published online: 22 March 2011

(C) The Author(s) 2011. This article is published with open access at Springerlink.com

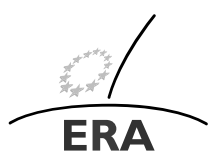

EUROPÄISCHE RECHTSAKADEMIE ACADEMY OF EUROPEAN LAW ACADEMIE DE DROIT EUROPEEN ACCADEMIA DI DIRITTO EUROPEO TRIER - TREVES - TREVIRI

\begin{abstract}
The European Small Claims Procedure is in general an instrument welcome for the enhancement it brings about to cross-border enforcement in the European Union. However, the regulation has several flaws, relating, inter alia, to its lack of consumer friendliness, and the lack of uniform rules regarding appeal and enforcement. It is further submitted that more attention should be paid to proper implementation and interpretation in the member states in order to facilitate the uniform application and the cross-border enforcement of small claims at the European level.
\end{abstract}

Keywords European small claims · Cross-border enforcement · Civil procedure

\section{Introduction}

The Regulation establishing a European Small Claims Procedure $^{1}$ (hereinafter abbreviated to ESCP) is one of the instruments of the 'second generation' that aims at enhancing cross-border enforcement in the European Union. While the other two relevant instruments in this area, the Regulation creating a European Enforcement Or-

\footnotetext{
${ }^{1}$ Regulation (EC) No 861/2007 of the European Parliament and of the Council of 11 July 2007 establishing a European Small Claims Procedure, O.J. 2007 L 199/1.
}

This paper is based on a lecture delivered at the ERA Conference 'Challenges for Cross-Border Litigation', held at Trier, 4-5 November 2010.

Prof. Dr. X.E. Kramer, Deputy-judge District Court Rotterdam, Professor of Private International Law and Comparative Law $(\bowtie)$

Erasmus University Rotterdam, Postbus 1738, 3000 DR Rotterdam, Netherlands

e-mail: kramer@frg.eur.nl 
$\operatorname{der}^{2}$ and the Regulation creating a European Order for Payment Procedure ${ }^{3}$ concern the enforcement of uncontested claims, the ESCP Regulation is the first instrument introducing a genuine European adversarial procedure. The ESCP has been established to enhance access to justice, in view of the disproportionate high costs for small claims, the long duration and complexity of litigation, as well as the substantial differences under national small claims procedures. ${ }^{4}$ The Treaty basis for this instrument was Article 65(c) of the EC Treaty, which has since then been incorporated into Article 81(f) TFEU, which concerns measures eliminating obstacles to the good functioning of civil proceedings.

The Regulation has been applicable since 1 January 2009 in all European Union member states, except Denmark. ${ }^{5}$ Its aim is to provide a uniform, simple and fast procedure for the recovery of claims with a value of up to $€ 2000$. Due to the Treaty requirement that measures in the area of judicial cooperation concern civil matters having cross-border implications, the ESCP may only be engaged where a crossborder case is concerned. ${ }^{6}$

The question is whether this relatively new European procedure is a valuable contribution to solving problems in international litigation, taking into consideration its implementation in the member states. This article examines the most important provisions of the Regulation and looks at its implementation in the member states. ${ }^{7}$

\section{The European small claims procedure}

\subsection{Scope of application and general outline}

Pursuant to Article 1, this Regulation establishes a European procedure for small claims, intended to simplify and speed up litigation concerning small claims in crossborder cases, and to reduce costs. As a consequence of the requirements of proportionality and subsidiarity, the ESCP is available to litigants only as an alternative to the procedures existing under the laws of the member state. ${ }^{8}$ It depends on the available procedures in the member state having jurisdiction which procedure is to be preferred in a particular case. Clear advantages are that the ESCP is available in all European Union countries, except Denmark, and that the standard forms attached to

\footnotetext{
${ }^{2}$ Regulation (EC) No 805/2004 of the European Parliament and of the Council of 21 April 2004 creating a European Enforcement Order for uncontested claims, O.J. 2004 L 143/15.

${ }^{3}$ Regulation (EC) No 1896/2006 of the European Parliament and of the Council of 12 December 2006 creating a European order for payment procedure, O.J. 2006 L 399/1.

${ }^{4}$ See also the Green Paper on a European order for payment procedure and on measures to simplify and speed up small claims litigation, 20 December 2002, COM(2002) 746 final, p. 49 ff and Recital 7 of the Regulation.

${ }^{5}$ Articles 29 and 2(3) ESCP.

${ }^{6}$ Articles 2 and 3 ESCP. The Commission proposal, COM(2005) 87 final, did not contain the limitation to cross-border cases. See, on this Proposal: Haibach [6]. See, on this limitation: Brokamp [1], pp. 16-17; Hess \& Bittmann [8], p. 306; Kramer [9], pp. 357-358.

${ }^{7}$ See in relation to the European Order for Payment Procedure: Kramer [12].

${ }^{8}$ See for an overview of national procedures: Mayer/Lindemann/Haibach [14], pp. 9-34.
} 
the Regulation simplify the initiation of procedures in a foreign court. Further, the judgment given in the ESCP is enforceable in the other member states without the need for a declaration of enforceability (exequatur). ${ }^{9}$

Article 2 of the ESCP Regulation provides that it shall apply, in cross-border cases, to civil and commercial matters, whatever the nature of the court or tribunal. ${ }^{10}$ The value of a claim, excluding interest, expenses and disbursements, should not exceed $€ 2000$ at the time when the claim form is received by the court with jurisdiction.

The substantive scope is largely derived from the Brussels I Regulation. The Regulation applies in civil and commercial matters, whatever the nature of the court or tribunal. It does not extend, in particular, to revenue, customs or administrative matters or to the liability of the State for acts and omissions in the exercise of State authority ("acta jure imperii"). The following matters are excluded: (a) the status or legal capacity of natural persons; (b) rights in property arising out of a matrimonial relationship, maintenance obligations, wills and succession; (c) bankruptcy; (d) social security; (e) arbitration; (f) employment law; (g) tenancies of immovable property, with the exception of actions on monetary claims; and (h) violations of privacy and of rights relating to personality, including defamation. Subject matters (a) to (e) largely coincide with the exclusions in Brussels I. The other subject matters are excluded because some member states have special procedures or even special courts for these cases. ${ }^{11}$ It is not required that the case involve a monetary claim, though it is necessary that the claim can be valued in money in order to assess whether it falls within the scope of the Regulation. ${ }^{12}$

The definition of a cross-border case is provided in Article 3, and coincides with that included in the European Payment Procedure Order Regulation. ${ }^{13}$ For the purposes of this Regulation, a cross-border case is one in which at least one of the parties is domiciled or habitually resident in a member state other than the member state of the court seized. Where alternative jurisdiction grounds apply, the choice for a particular court may thus influence the applicability of the Regulation. It is not required that both parties are domiciled or habitually resident in the European Union. ${ }^{14}$

The threshold of $€ 2000$ has been debated during the negotiations. Several member states found it too low, whereas others-including many of the new European Union member states - found it too high. ${ }^{15}$ The European Economic and Social Committee expressed in its opinion on the Commission proposal that the ceiling of $€ 2000$ was clearly insufficient given the current value of goods and services. ${ }^{16}$ It is noteworthy that this limit was given particular mention in the review clause in Article 28 of the

\footnotetext{
${ }^{9}$ Articles 1(2) and 20 ESCP.

${ }^{10}$ The Regulation mentions 'court or tribunal' in all relevant provisions. In this article, however, reference will from this point be made only to the 'court'.

${ }^{11}$ See also Council of the European Union Comments on the specific articles of the proposal, $21 \mathrm{March}$ 2005, JUSTCIV 54, CODEC 177.

${ }^{12}$ Article 5(5) ESCP specifically mentions non-monetary claims. See Erauw \& Storme [2], p. 213.

${ }^{13}$ See, more in detail: Fiorini [3], pp. 460-463.

${ }^{14}$ Hess [7], p. 577, no. 91; Mayer/Lindemann/Haibach [14], p. 58, no. 474.

${ }^{15}$ See, Kramer [9], pp. 360-361.

${ }^{16}$ Opinion EESC O.J. 2006, C 88/61, comment 6.1.
} 
ESCP Regulation as one of the issues to be considered in the report on the operation of the ESCP Regulation to be submitted by 1 January 2014. During the Council negotiations there has also been a debate on dealing with counterclaims. ${ }^{17}$ Article 5(7) of the ESCP Regulation provides that if the counterclaim exceeds the limit of $€ 2000$, the claim and counterclaim shall not proceed in the ESCP, but be dealt with in accordance with national law. ${ }^{18}$ This may limit the scope considerably.

The Regulation provides the most important procedural rules and minimum requirements, but is certainly not exhaustive. Pursuant to Article 19, subject to the other provisions of the Regulation, the ESCP is to be governed by the procedural law of the member state in which the procedure is conducted. The Recitals to the Regulation state that the court should respect the right to a fair trial and the principle of an adversarial process. ${ }^{19}$ The procedure is conducted by means of four standard forms, which are attached to the Regulation. These are the claim form (form A), a form to request completion or correction of the claim form (form B), an answer form (form C), and a certificate concerning a judgment in the ESCP (form D). ${ }^{20}$ These standard forms are essential to the success of the ESCP, and have been carefully drafted. However, some questions may prove to be difficult for the average consumer. ${ }^{21}$ The forms are available in all the official European Union languages at the European Judicial Atlas and may be filled out on-line. ${ }^{22}$ The answer and claim form contain closed fields and use a tick-box system where possible, and provide a short explanation per item. According to Article 11, member states shall ensure that the parties can receive practical assistance in filling in the forms. ${ }^{23}$ Information about procedural questions can also be given by the court staff in accordance with national law. ${ }^{24}$

As a rule, the ESCP is conducted in writing. Representation by a lawyer or other legal professional is not mandatory, and there are special rules for the taking of evidence and the hearing. The time limits for the various stages of the procedure are important, both for the parties and for the court.

\subsection{Commencement of the procedure and international jurisdiction}

The ESCP is commenced by lodging the claim form at the competent court, pursuant to Article 4 of the Regulation. The claim form may be lodged directly, by post or by any other means of communication such as by fax or e-mail, as long as this is acceptable to the member state in which the procedure is commenced. Information on the

\footnotetext{
${ }^{17}$ The concept of counterclaim should be interpreted within the meaning of Article 6(3) Brussels Regulation, see Recital 16 ESCP.

${ }^{18}$ Article 4(2) of the Commission proposal provided that in case the value of the counterclaim exceeded $€ 2000$, the counterclaim would only be considered if it arose from the same legal relationship and if the court considered it appropriate to proceed in the ESCP.

${ }^{19}$ Recital 9 ESCP.

${ }^{20}$ See for a practical guide in German: Mayer/Lindemann/Haibach [14].

${ }^{21}$ Such as question 4 of the claim form regarding international jurisdiction.

${ }^{22}$ See http://ec.europa.eu/justice_home/judicialatlascivil/html/index_en.htm.

${ }^{23}$ See also Recital 21 ESCP.

${ }^{24}$ Recital 22 ESCP.
} 
acceptable means of communication is available at the Judicial Atlas. ${ }^{25}$ One of the points of debate during the negotiations on the Commission proposal was whether evidence should be lodged with the court together with the claim form. To avoid unnecessary translation costs, the Regulation provides that the claim form shall include a description of the evidence, and only where appropriate be accompanied by supporting documents. It goes without saying that, if necessary, the court may require submission of written evidence or other evidence in the course of the proceedings. ${ }^{26}$

Where a claim is outside the scope of the Regulation, the court shall inform the claimant, and the court will proceed in accordance with national law, unless the claimant withdraws the claim. Where the court considers the information provided inadequate or insufficiently clear, or else the form is not filled in properly, the court will give the opportunity to complete or rectify the form using form $\mathrm{B}$, unless the claim appears to be clearly unfounded or the application inadmissible. Where the claim appears to be clearly unfounded or the application inadmissible or where the claimant fails to complete or rectify the claim form within the time specified, the application shall be dismissed. The Recitals clarify that the concepts 'clearly unfounded' and 'inadmissible' should be determined in accordance with national law. ${ }^{27}$

The ESCP Regulation does not contain international jurisdiction rules. Item 4 of the claim form specifies that the court/tribunal must have jurisdiction in accordance with the rules of the Brussels I Regulation. ${ }^{28}$ This is remarkable, since it is clear from Article 3 that the ESCP Regulation also applies where a party/defendant only has his habitual residence in an European Union member state. ${ }^{29}$ Unlike Article 6(1)(d) of the European Enforcement Order Regulation and Article 6(2) European Payment Procedure Order Regulation, the ESCP Regulation does not contain an exclusive jurisdiction rule for consumers. Consequently, the general-and more limited-rules of Article 15 to 17 of the Brussels I Regulation apply. ${ }^{30}$ The background probably is that those Regulations concern uncontested claims while the ESCP Regulation, in principle, does not, so it will be up to the consumer to contest jurisdiction. This, however, does not explain why the definition of 'consumer' is broader under those Regulations than under the ESCP Regulation. Furthermore, unlike the position under the current Brussels I Regulation, the decision in the ESCP is enforceable throughout the European Union, so the consumer does not get any protection at the stage of recognition and enforcement. ${ }^{31}$ Since small claims litigation mostly involves consumer cases, a similar protective rule for the ESCP would in my opinion have been appropriate.

\footnotetext{
${ }^{25}$ See further Sect. 3.1, below.

${ }^{26}$ See Art. 9 ESCP on the taking of evidence.

${ }^{27}$ Recital 13 ESCP.

${ }^{28}$ Hess [7], p. 577, no. 91.

${ }^{29}$ See also on this issue, Brokamp [1], p. 19.

${ }^{30}$ The mentioned provisions include all natural persons, and do not contain the restrictions of Article 15 Brussels I Regulation that the professional directs activities at the member state of the consumer.

${ }^{31}$ See Article 35(1) Brussels I Regulation.
} 


\subsection{Conduct and conclusion of the procedure}

Article 5(1) provides that the ESCP is to be a written procedure. During the negotiations the right to an oral hearing was one of the issues debated, due to the tension between, on the one hand, costs and efficiency and, on the other hand, the right to a fair hearing. ${ }^{32}$ The court is required to hold an oral hearing if it considers this to be necessary or if a party so requests. This request may be refused if the court considers that with regard to the circumstances of the case, an oral hearing is obviously not necessary for the fair conduct of the case. The reasons thereto shall be given in writing. In this author's view, this rule is consistent with the requirements of Article 6 of the European Convention on Human Rights. ${ }^{33}$

Article 5 further regulates that within fourteen days of receiving the properly filled-in claim form, a copy of the claim form and possible supporting documents, together with the standard answer form $\mathrm{C}$, shall be served on the defendant in accordance with Article 13. The defendant shall submit his response within thirty days of service by filling in standard answer form $\mathrm{C}$, where appropriate accompanied by any relevant supporting documents, or in any other appropriate way, and returning it to the court. Within fourteen days of receipt of the response from the defendant, the court shall dispatch a copy thereof, together with any relevant supporting document to the claimant. ${ }^{34}$ The claimant shall have thirty days from service to respond to any counterclaim.

A strong point of the Regulation consists of the language requirements laid down in Article 6. The claim form, the response, the counterclaim and response thereto, and any description of relevant supporting documents, is required to be submitted in the language, or one of the languages, of the court. The court may require a translation of documents received in another language only if the translation appears to be necessary for giving the judgment. In compliance with Article 8 of the Service Regulation, a party may refuse to accept a document when it is not in the official language of the (the place in a) member state where service is to be effected or where the document is to be dispatched, or in a language which the addressee understands. ${ }^{35}$ Other procedural rules are laid down in Articles 8-14 of the ESCP Regulation. An oral hearing may be held through video conference or other communication technology if the technical means are available (Article 8). The court shall determine the means of taking evidence and the extent of the evidence necessary for its judgment under the (national) rules applicable to the admissibility of evidence (Article 9). The court may allow the taking of evidence through written statements of witnesses, experts or

\footnotetext{
${ }^{32}$ See also Council of the European Union, 29 November 2005, doc. no. 15054/05, JUSTCIV 221, CODEC 1107. The Commission proposal provided that an oral hearing may take place when the court deems it necessary.

${ }^{33}$ See more in detail, Brokamp [1], pp. 113-125; Hess [7], pp. 577-578, no 93; Kramer [9], p. 371.

${ }^{34}$ If the defendant claims that the value of a non-monetary claim exceeds $€ 2000$, the court is required, within thirty days of dispatching the response to the claimant, decide whether the claim is within the scope of the ESCP (Art. 5(5)).

${ }^{35}$ The case law of the European Court of Justice in relation to the Service Regulation is important for the interpretation of this provision, particularly Case C-14/07 Weiss und Partner [2008] ECR I-3367.
} 
parties. It may allow the taking of evidence through video conference or other available technical means. In view of the costs, the court may take expert evidence or oral testimony only if it is necessary for giving the judgment. In any case, the court shall use the simplest and least burdensome method of taking evidence. Representation by a lawyer or another legal professional shall not be mandatory (Article 10), and practical assistance in filling in the forms is required to be made available (Article 11). Parties are not required to make any legal assessment of the claim. The court is to inform the parties about procedural questions, and whenever appropriate, the court is to seek to reach a settlement between the parties (Article 12).

The conclusion of the procedure is regulated in Article 7. Within thirty days of receipt of the timely response from the defendant, or from claimant to the counterclaim, the court is required either to give judgment, or to demand further details (within a maximum period of thirty days), or to take evidence in accordance with Article 9, or to summon the parties to an oral hearing to be held within thirty days of the summons. The court is required to give judgment either within thirty days of any oral hearing or after having received all information necessary for giving the judgment. If it has not received an answer from the party within the set time limits, it shall give a judgment on the claim or the counterclaim. The Commission proposal provided for a 'final deadline' for the judgment of six months following the registration of the form. However, many delegations had doubts on setting a binding overall limit for the whole procedure besides the time limits for specific procedural phases, and it was therefore deleted. ${ }^{36}$ In my opinion, this is regrettable since an additional overall time limit of six months would have provided a clearer framework and incentive.

In order to reduce costs, the Regulation has an autonomous rule that provides for a simple and mandatory means of service of documents. ${ }^{37}$ Pursuant to Article 13(1), documents are to be served by postal service attested by acknowledgement of receipt, including the date of receipt. If service in accordance with Article 13(1) is not possible, service may be effected by any of the methods provided for in Articles 13 or 14 of the European Enforcement Order Regulation. These provide for ten different methods of service of documents. ${ }^{38}$

The inclusion of strict time limits in the Regulation is extremely important to ensure that small claims can indeed be recovered within a short period. Article 14 provides, as regards the time limits the court sets, that the party concerned shall be informed of the consequences of not complying with them (Article 14). In exceptional circumstances, if this is necessary to safeguard the rights of the parties, the time limits may be extended. ${ }^{39}$

\subsection{Recognition and enforcement}

The judgment is to be enforceable notwithstanding any possible appeal, and without security required (Article 15). Enforcement in another member state is regulated

\footnotetext{
${ }^{36}$ Council of the European Union, 29 November 2005, doc. no. 15054/05, JUSTCIV 221, CODEC 1107.

${ }^{37}$ Hess [7], pp. 578-579, no 95.

${ }^{38}$ See for a comprehensive discussion of these methods: Rauscher [17], p. $45 \mathrm{ff}$.

${ }^{39}$ See for a detailed overview of the conduct of the ESCP: Brokamp [1], pp. 23-130.
} 
by Articles 20-23, which for the most part duplicate the relevant rules of the European Enforcement Order and European Payment Procedure Order Regulations. The judgment given in a member state in the ESCP shall be recognised and enforced in another member state without the need for a declaration of enforceability or the possibility of opposing its recognition (Article 20). At the request of one of the parties a certificate concerning a judgment in the ESCP (standard form D) will be issued. The enforcement shall be governed by the law of the member state of enforcement (Article 21). The party seeking enforcement is to produce an authentic copy of the judgment, and a copy of the certificate mentioned in Article 20(2), where necessary with a translation thereof into the language of the member state of enforcement, or into another language that the member state has indicated it will accept. ${ }^{40}$ The only ground of refusal is irreconcilability with an earlier judgment of a European Union member state or of a third country, provided that it involves the same cause of action and that it was between the same parties (Article 22). Additional requirements are that this decision be given by the member state of enforcement or be enforceable in that member state, and that the irreconcilability could not have been raised as an objection in the member state where the judgment was given. Where a party has challenged the ESCP judgment or where such a challenge is still possible, enforcement proceedings may be limited to protective measures, or be made conditional on the provision of security, or under exceptional circumstances be stayed (Article 23).

As is the case for the European Enforcement Order and European Payment Procedure Order Regulations, possible enforcement measures have not been exhaustively regulated in the ESCP Regulation. This leaves unanswered the question of whether national enforcement measures may still play a role as well in relation to the ESCP Regulation. $^{41}$

\subsection{Appeal and review}

A weakness of the Regulation is that it does not provide for a uniform rule on appeal. Including such a rule was regarded as undesirable in view of the substantial differences in the member states in this regard. ${ }^{42}$ This question was thus left to national law. According to Article 17, member states had to inform the Commission whether an appeal is available and within what time limit. ${ }^{43}$ It is unclear whether the procedural rules included in the Regulation apply to the appeal procedure. Article 17 only provides that Article 16 (regarding costs) applies. In this respect, it is questionable whether the appeal judgment is to be regarded as a judgment in the ESCP and qualifies as a European title that is enforceable without exequatur. On the one hand, this would be desirable so as not to undermine the uniform nature of the ESCP. On the other hand, this would seem somewhat peculiar since the Regulation does not pro-

\footnotetext{
${ }^{40}$ See Article 25 and the information provided on the Judicial Atlas, and Sect. 3.1 below.

${ }^{41}$ See also Hess [7], p. 582, no. 106.

${ }^{42}$ Commission staff working document, Comments on the specific articles of the proposal, $\operatorname{COM}(2005)$ 87 final, Art. 15.

${ }^{43}$ See further Sect. 3.1 below.
} 
vide rules for the appeal procedure, and this would mean that an in essence a national procedure would result in a European judgment.

Following the European Enforcement Order and European Payment Procedure Order Regulations, the ESCP Regulation does provide for minimum standards for review of judgments. Pursuant to Article 18, the defendant shall be entitled to apply for a review before the court with jurisdiction of the member state where judgment was given where: (a) the claim form or summons to an oral hearing were served by a method without proof of receipt by the defendant personally as provided for in Article 14 of the European Enforcement Order Regulation, and service was not effected in sufficient time to enable him to arrange for his defence without any fault on his part; or (b) the defendant was prevented from objecting to the claim by reason of force majeure, or due to extraordinary circumstances without any fault on his part. In both cases the defendant should act promptly. It is not clear what exactly is to be understood by 'extraordinary circumstances'. What is clear is that the defendant must not have been able to defend his case without fault on his or her part. This rule is intended to guarantee a possibility of review in situations where the defendant was not able to contest the claim, and to comply with the requirement of a fair trial guaranteed by Article 6 of the European Convention on Human Rights. $^{44}$

\subsection{Costs}

Given the aim of reducing costs for small claims litigation, the rule regarding costs was the subject of some debate. Article 16 of the Regulation provides that the unsuccessful party is to bear the costs of the proceedings. The court is not, however, to award costs that were unnecessarily incurred or disproportionate to the claim. The Commission proposal provided that the unsuccessful party should bear the costs of the proceedings unless this would be unfair or unreasonable, and that when the unsuccessful party was a natural person and was not represented by a lawyer, he should not be obliged to reimburse the lawyer's fee of the other party. This was meant to encourage parties not to employ a lawyer. ${ }^{45}$ However, several delegations preferred to apply the principle that the losing party has to pay irrespective of whether he is a natural or legal person. ${ }^{46}$ The application of the criteria employed in Article 16 is not unproblematic, since national laws differ in this regard. ${ }^{47}$

As to the costs of the proceedings the Recitals state that it should be necessary to have regard to the principles of simplicity, speed and proportionality when setting the costs of dealing with a claim under the ESCP. ${ }^{48}$ It is appropriate that details of the costs to be charged be made public, and that the means of setting any such costs are transparent. Unfortunately, the information provided by the member states does not offer much clarity on costs.

\footnotetext{
${ }^{44}$ Recital 31 ESCP.

${ }^{45}$ See Article 14 Commission proposal; Comments on the specific articles of the proposal, Art. 14.

${ }^{46}$ Council of the European Union, 21 November 2005, doc. no. 14638/05, JUSTCIV 208, CODEC 1037, 6.

${ }^{47}$ See further on the cost rule: Brokamp [1], pp. 141-148.

${ }^{48}$ Preamble no 7 ESCP.
} 


\section{Implementation in the member states}

\subsection{Implementation requirements under Article 25}

\subsubsection{General remarks}

The ESCP Regulation has direct binding force, and thus does not require implementation as such, but since it is not exhaustive, national procedural law will be complementary (Article 19). Article 25 further explicates five issues that had to be communicated to the Commission one year prior to its applicability, and made public by the Commission. This information concerns: (a) which courts or tribunals have jurisdiction to give a judgment in the ESCP; (b) which means of communication are accepted and available (see Article 4); (c) whether an appeal is possible, and with which court or tribunal this may be lodged; (d) which languages are accepted for the purpose of enforcement (see Article 22); and (e) which authorities have competence with respect to enforcement, and a stay or limitation thereof (see Article 23). This information has been published in the Official Journal and made available on the Judicial Atlas website. Research conducted six months after the applicability showed that the information relating to seven member states was not yet available on the website, ${ }^{49}$ but in the meantime it has become available.

The degree of detail as well as the content of the information provided differs substantially as between member states. Some member states have enacted extensive implementation laws. For example Germany, France and England and Wales have enacted proper implementation rules that are incorporated in the existing procedural codes. ${ }^{50}$ The Netherlands has a separate implementation Act for this purpose. ${ }^{51}$ Some other member states have made only certain ad hoc provisions in order to fulfill the obligation to provide the requested information. An example of such a member state is Belgium, where a small survey conducted in 2010 showed that this procedure is still unknown to the general public and to some courts. ${ }^{52}$

\subsubsection{The Courts having jurisdiction}

For the courts having jurisdiction to give judgment in the ESCP, most member states simply refer to the court of first instance that is also competent for national small claims cases. This is the local court (for example, a justice of the peace or a cantonal court), the District Court, or in some instances a special small claims court. The ordinary rules of subject matter and territorial jurisdiction apply. Finland is the

\footnotetext{
${ }^{49}$ Kramer [11], p. 121.

${ }^{50}$ Germany: §1097-1109 Zivilprozessordnung (ZPO); France: Articles 1382-1392 Code de procedure civile; England and Wales: Part 78.12-78.22 of the Civil Procedure Rules (CPR), complemented by Practice Direction 78 (PD). Particularly Germany and England and Wales provide extensive rules.

${ }^{51}$ Uitvoeringswet verordening Europese procedure voor geringe vorderingen (including 10 articles).

${ }^{52}$ See from a Belgian perspective: Storme [18]. A Belgian consumer organisation 'Test-aankoop' concluded in a survey conducted in 2010 that neither consumers nor the judiciary were familiar with this procedure, see http://www.test-aankoop.be/klachten-en-rechtsprocedures/justitie-in-gebreketoegang-tot-het-gerecht-moet-eenvoudiger-voor-kleine-grensoverschrijdende-geschillen-s658483.htm.
} 
only member state that provides that the District Court of Helsinki has jurisdiction. The Finnish judicial system does not depend on the size of the claim and thus no 'small claims' court exists. ${ }^{53}$ In relation to the European Payment Procedure Order, the question arose whether designating a centralised court is in conformity with the Brussels I Regulation, since some of these rules also designate territorial jurisdiction within member states. ${ }^{54}$ However, in a communication the European Commission clarified that a centralised court for the purpose of handling the European Payment Procedure Order was allowed. ${ }^{55}$ The question is whether the same holds true for the ESCP.

\subsubsection{Acceptable means of communication}

As regards the means of communication, it is interesting to note that most member states accept only submission by (registered) postal mail, and (in most cases) direct submission to the court. Ten member states stipulate that submission by fax is possible. Eight member states indicate that it is possible (in all or some courts) to submit the claim form in electronic form. ${ }^{56}$ In this regard, most member states generally mention that the claim may be submitted by e-mail. Some member states have other specific electronic systems. For example, Austria has a web-based e-justice system in place that is known for being successful in national cases and the European Payment Procedure Order proceedings as well.

\subsubsection{Appeals}

Regarding the question of whether appeal against a judgment in a ESCP is possible, most member states refer to the ordinary rules on appeals. This requires further research on possible thresholds or limits under national law. In most member states, an appeal is possible, though several member states mention monetary thresholds, ${ }^{57}$ or only allow further appeal or cassation. ${ }^{58}$ Some member states have excluded the possibility of appeal entirely, or provide less liberal rules than in national cases. ${ }^{59}$ For example, in the Netherlands the general threshold for lodging appeals is $€ 1750$, but the Dutch Implementation Act provides that an appeal from the judgment in the ESCP is excluded. The Ministry of Justice has argued that the difference between

\footnotetext{
${ }^{53}$ Mayer/Lindemann/Haibach [14], pp. 11-12 and the information available on the European Judicial Network in Civil and Commercial Matters, see http://ec.europa.eu/civiljustice/.

${ }^{54}$ Most important in this regard is Article 5(1) Brussels I, which refers to the place where the obligation has to be performed or where the delivery took place.

${ }^{55}$ Communication European Commission, 5 December 2008. See also on this issue in relation to the European Payment Procedure Order: Van der Grinten [4], p. 124.

${ }^{56}$ Czech Republic, Estonia, Cyprus, Austria, Portugal, Slovenia, Slovakia. In Germany several courts enable filing the claim form electronically. In the United Kingdom the claim form has to submitted by postal mail, but additional documents may be send by e-mail.

${ }^{57}$ As stipulated in relation to the ESCP by Bulgaria, Czech Republic, and Malta.

${ }^{58}$ Luxembourg and Greece.

${ }^{59}$ The Netherlands, Greece and France.
} 
ordinary Dutch procedures and the ESCP in this regard is only minor. However, since the national threshold includes costs and interests, and the ESCP threshold excludes costs and interests, the differences may be (much) bigger than $€ 250$. This distinction has rightly been criticised in the literature. ${ }^{60}$

It may be noted that in several instances the information provided is quite brief and not very helpful for the non-specialised user due to the general reference to the competent court and lack of information on the appeal period.

\subsubsection{Language requirements for enforcement}

As regards the acceptable languages for the purpose of enforcement under Article 21(2)(b), by far the greater number of member states accept only their official national language or languages. Several member states also accept English, or English and one other language. ${ }^{61}$ France is very liberal, and accepts judgments in English, German, Italian, and Spanish. This is remarkable, since France is of course not a multilingual country and not known for its linguistic skills. It may be concluded that in most cases the judgment needs translation if it is to be enforced in another member state.

\subsubsection{Enforcement authorities}

The relevant enforcement authorities mentioned are the (public and/or private) court bailiffs, the courts or District Court having jurisdiction in the main proceedings, court executors or special enforcement officers. The authorities having competence in regard of a refusal, stay or limitation of enforcement are not always mentioned, but as far as information is provided, it is the court having jurisdiction in the ESCP in general $^{62}$ or at the place of enforcement ${ }^{63}$ or to which the bailiff was appointed, ${ }^{64}$ the summary proceedings judge ${ }^{65}$ another special judge, ${ }^{66}$ the enforcement authority/bailiff, ${ }^{67}$ or multiple courts which have jurisdiction. ${ }^{68}$ The information is in most cases not very specific; additional information may be available through the European Judicial Network.

\subsection{Some first practical experiences: the example of the Netherlands}

In the Netherlands, the implementation of the European Small Claims Procedure has been taken up seriously by way of an Implementation Act. Judges are usually wellinformed through ad hoc courses and the study of literature. Two years after the

\footnotetext{
${ }^{60}$ De Moor [16], p. 505.

${ }^{61}$ Estonia (English), Cyprus (English), Malta (English), Finland (Swedish and English), Sweden (English).

${ }^{62}$ See for example Greece, Spain, and Ireland.

${ }^{63}$ Lithuania.

${ }^{64}$ Hungary.

${ }^{65}$ France.

${ }^{66}$ Malta (Court of Magistrates). Lithuania refers for the question of refusal in case of irreconcilability to the Court of Appeal.

${ }^{67}$ Romania, Finland, and Sweden.

${ }^{68}$ The Netherlands, Austria, and Portugal.
} 
Regulation entered into force, six cases have been reported. ${ }^{69}$ Since only a small proportion of all judgments are actually published, ${ }^{70}$ this does not mean that this procedure has only been used six times, which would admittedly be somewhat disappointing. ESCP judgments have been rendered by four different courts, between the period February-December 2010. For unknown reasons, there are no published judgments available from the year 2009.

In five instances, a consumer case was involved; in three of these cases the consumer was the claimant and in the other two cases the company (in both instances a law firm claiming fees). In all three cases where the consumer was the claimant, a Dutch consumer was concerned, litigating against a foreign company. ${ }^{71}$ Since in these cases the amounts involved varied from $€ 99$ to $€ 450$, it would perhaps not have been worth the effort and money involved in initiating national proceedings. ${ }^{72}$ In all five cases, the claim was granted, including legal costs of up to $€ 250$. The sixth case concerned a $\mathrm{C} 2 \mathrm{C}$ case, where goods had been sold through the internet. The duration of the proceedings varied from one and a half months up to seven months, the average length being four months. This is reasonable and in compliance with the aims of the Regulation, particularly considering that in most cases the defendant did submit an answer form.

From the evidence of these few published cases, the application of the ESCP does not seem particularly problematic. ${ }^{73}$ In the cases, the court established the applicability of the Regulation, particularly as regards the monetary limit and the cross-border nature, as well as its international jurisdiction and, where necessary, the applicable law. In one case the Latvian defendant invoked the language requirements of Article 6 , but the court simply denied this defence. It reasoned that the claim form had been submitted in Dutch as the language of the court, and that the defendant had not substantiated its defence. However, Article 6 also deals with the language requirements in relation to the defendant. The ruling in the case is not clear on what language the defendant received the relevant documents in, however.

\section{Some concluding remarks}

The European Small Claims Procedure is an important step towards the establishment of a European civil procedural law and the enforcement of small claims. Generally, the rules as well as the standard forms are clear and carefully drafted. However, as

\footnotetext{
${ }^{69}$ For this research case law surveys have been made, mostly using the publicly available databank of case law on www.rechtspraak.nl. In one case an interim judgment and a final judgment were rendered. The cases are: District Court Maastricht, 5 February 2010, LJN: BL5933; District Court Maastricht, 5 February 2010, LJN: BL 4324; District Court Groningen, 8 March 2010, LJN: B02532 (interim judgment) and 26 June 2010, LJN: B02533; District Court Amsterdam, 30 August 2010, LJN: B02995; District Court'sHertogenbosch, 13 February 2010, LJN: B07878.

${ }^{70}$ Mommers, Zwenne \& Schermer [15] provide research to the effect that only $1 \%$ of cases decided are published, arguing that this makes sound qualitative or even quantitative research impossible.

${ }^{71}$ The defendants were a Belgian furniture company, Deutsche Bahn and Latvian Air Baltic.

${ }^{72}$ The use of standard forms is not common in the Netherlands, and proceedings would probably have taken longer and been more complicated.

${ }^{73}$ The present author did incidentally receive questions from courts on the application of the ESCP.
} 
explained above, an overall time limit would have been preferable, the consumer friendliness of the rules in relation to international jurisdiction may be questioned, the lack of a rule regarding appeal substantially undermines uniform application, and the minimum rules on review are unclear. Attention has been paid to horizontal coherence with, in particular, the European Enforcement Order and European Payment Procedure Order Regulations. However, this also means that some of the flaws of these Regulations are inherited. An example is the above-mentioned lack of clarity regarding the extent of the minimum rules on review. Another example is the limited regulation of enforcement, which leaves doubt as to the possibility of national enforcement measures. The implementation of the ESCP Regulation, as well as several other Regulations, deserves more serious attention from the European legislature, and from some of the member states as well. A practical hand guide would have been preferable in order to facilitate proper implementation and application.

A general criticism with which this contribution may be concluded is that the sectoral approach taken by the European legislature results in a fragmented European civil procedure that does not rely on a clear view on fundamental principles or of the future of European civil procedure. ${ }^{74}$ The co-existence of the Brussels I Regulation, the European Enforcement Order Regulation, the European Payment Procedure Order Regulation and the ESCP Regulation with the inherent differences which this involves in relation to, amongst other matters, the enforcement and service of documents, does not contribute to a transparent European civil procedure. This calls for a fundamental rethinking of European civil procedure. ${ }^{75}$

Open Access This article is distributed under the terms of the Creative Commons Attribution Noncommercial License which permits any noncommercial use, distribution, and reproduction in any medium, provided the original author(s) and source are credited.

\section{References}

1. Brokamp, A.: Das Europäische Verfahren für geringfügige Forderungen. Mohr Siebeck, Tübingen (2008)

2. Erauw, J., Storme, H.: Beginselen van Belgisch privaatrecht. In: XVII. Internationaal Privaatrecht, Deventer. Kluwer, Dordrecht (2009)

3. Fiorini, F.: Facilitating cross-border debt recovery - the European payment order and the small claims regulations. Int. Comp. Law Q. 57, 449-465 (2008)

4. van der Grinten, P.M.M.: De inbedding van de Europese betalingsbevelprocedure in het Nederlandse burgerlijk procesrecht: een leerzaam proces. In: Polak, M.V. (ed.) Inbedding van Europese Procesrechtelijke Normen in de Nederlandse Rechtsorde, pp. 109-128. Ars Aequi Libri, Nijmegen (2010)

5. van der Grinten, P.M.M.: Challenges for the creation of a European law of civil procedure. Available at http://ssrn.com/abstract=1392006 (2009)

6. Haibach, G.: The commission proposal for a regulation establishing a European small claims procedure: an analysis. Eur. Rev. Priv. Law, 593-601 (2005)

7. Hess, B.: Europäsches Zivilprozessrecht. Ein Lehrbuch. C.F. Müller Verlag, Heidelberg (2010)

8. Hess, B., Bittmann, D.: Die Verordnungen zur Einführung eines Europäischen Mahnverfahrens und eines Europäischen Verfahrens für geringfügige Forderungen-ein substantieller Integrationsschritt im Europäischen Zivilprozessrecht. Prax. Int. Priv. Verfah., 305-314 (2008)

\footnotetext{
${ }^{74}$ See also Kramer [10], pp. 276-282.

${ }^{75}$ See for valuable contributions to this debate inter alia: Van der Grinten [5]; Tulibacka [19]; various contributions in Kramer \& Van Rhee [13].
} 
9. Kramer, X.E.: The European small claims procedure: striking the balance between simplicity and fairness in European litigation. Z. Europäisches Priv., 355-373 (2008)

10. Kramer, X.E.: A major step in the harmonization of procedural law in Europe: the European small claims procedure. Accomplishments, new features and some fundamental questions of European harmonization. In: Jongbloed, A.W. (ed.) The XIIIth World Congress of Procedural Law: The Belgian and Dutch Reports, pp. 253-283. Intersentia, Antwerp (2008)

11. Kramer, X.E.: Het IPR voorbij: de invoering van eenvormige Europese procedures. De Europese betalingsbevelprocedure en de Europese procedure voor de inning van geringe vorderingen. In: Erauw, J., Taelman, P. (eds.) Nieuw internationaal privaatrecht. Meer Europees, meer globaal, Mechelen, 2009, pp. 79-128. Kluwer, Dordrecht (2009)

12. Kramer, X.E.: Enhancing enforcement in the European Union: the European order for payment procedure and its implementation in the member states, particularly in Germany, the Netherlands and England. In: Van Rhee, C.H., Uzelac, A. (eds.) Enforcement and Enforceability. Tradition and Reform, pp. 17-39. Intersentia, Antwerp-Oxford-Portland (2010)

13. Kramer, X.E., Van Rhee, C.H.: Civil Litigation in a Globalizing World. Asser Press, The Hague (2011)

14. Mayer, H.-P., Lindemann, J., Haibach, G.: Small Claims Verordnung. Klage, Verfahren, Urteil und Vollstreckung geringfügiger Forderungen in Europa. C.H. Beck, München (2009)

15. Mommers, L., Zwenne, G.J., Schermer, B.: Het best bewaarde geheim van de raadkamer. Over de ontoegankelijkheid van de rechtspraak. Ned. Jurist., 2072-2078 (2010)

16. de Moor, R.: Uitsluiting hoger beroep bij Europese procedure voor geringe vorderingen: geen gering verschil met nationaal recht. Ned. Jurist., 504-505 (2009)

17. Rauscher, T.: Der Europaïsche Vollstreckungstitel für unbestrittene Forderungen. Sellier/Verlag Recht und Wirtschaft, München/Heidelberg (2004)

18. Storme, M.: De verhouding tussen de Europese procesrechtelijke verordeningen (in het bijzonder geringe vorderingen) en het interne Belgische procesrecht. Available at http://www.storme.be/ euinvordering.pdf (2010)

19. Tulibacka, M.: Europeanization of civil procedures: in search of a coherent approach. Common Mark. Law Rev. 46, 1527-1565 (2009) 